\title{
Community's knowledge, attitudes and practices about tuberculosis in Itang Special District, Gambella Region, South Western Ethiopia
}

\author{
Jango Bati ${ }^{1}$, Mengistu Legesse ${ }^{2^{*}}$ and Girmay Medhin ${ }^{2}$
}

\begin{abstract}
Background: Tuberculosis (TB) is one of the primary public health problems in developing countries. HIV/AIDS, poverty, undernutrition, over-crowded living conditions and lack of knowledge about the disease have been known to increase the risk of spreading the bacteria and the risk of developing the disease. The objective of this study was to assess the level of TB knowledge, attitudes and practices of rural communities of Itang Special District of the Gambella Regional State of Ethiopia.
\end{abstract}

Methods: Between November 2011 and January 2012, a community-based cross sectional study was carried out in a randomly selected rural kebeles (i.e. the smallest administrative units) of Itang communities. The study participants were interviewed using pre-tested questionnaire. The overall knowledge, attitudes and practices of the study participants were assessed using the mean score of each outcome as a cut-off value. Having a score above the mean on each of the three target outcomes was equated with having a good level of knowledge, or having favorable attitude and good practices towards TB.

Results: Out of 422 study participants (58.5\% males and $41.5 \%$ females) only $3.3 \%$ mentioned bacteria/germ as a cause of pulmonary TB (PTB) and 9.9\% mentioned cough for at least two weeks as the sign of TB. Taking the mean knowledge score as the cut-off value, 57.6\% (95\% Cl: 52.7\% to 62.3\%) of the study participants had good level of knowledge about TB, 40.8\% (95\% Cl: 36.0\% to 45.6\%) had favorable attitude towards TB and 45.9\% (95\% Cl: 41.1\% to 50.9\%) had good practices. Female participants were less likely to have good level of knowledge [adjusted odds ratio $(A O R)=0.33,95 \% C l, 0.21$ to $0.51, p<0.001$ ], less likely to have favorable attitude ( $\mathrm{OOR}=0.23,95 \% \mathrm{Cl}, 0.14$ to 0.37 ) and less likely to have good practices ( $A O R=0.37,95 \% \mathrm{Cl}, 0.24$ to $0.57, \mathrm{p}<0.001$ ) compared to male participants.

Conclusion: Majority of the study participants had no correct information about the causative agent of TB and the main symptom of PTB. Moreover, low level of overall knowledge, attitudes and practices about TB was associated with female participants. Hence, TB control strategy in the present study area should include community awareness raising component.

\section{Background}

Tuberculosis (TB) is a chronic bacterial disease mainly caused by Mycobacterium tuberculosis (M.tb) [1]. The disease is mainly transmitted through air droplets, cough, and sneeze, when patient expels droplets containing bacilli and inhaled by healthy individuals. Although TB primarily

\footnotetext{
* Correspondence: dlegessem@yahoo.com

${ }^{2}$ Addis Ababa University, Aklilu Lemma Institute of Pathobiology,

Addis Ababa, P.O. Box, 1176, Ethiopia

Full list of author information is available at the end of the article
}

affects the lungs it also affects any part of the body including kidney, brain, intestine, bone and lymph nodes [2].

Each year, an individual with active Pulmonary Tuberculosis (PTB) infects an average of 10-15 people [3]. Moreover, in a community with low levels of awareness about the cause, mode of transmission and preventive methods, the spreading of TB could be high $[4,5]$. The estimates for the year 2010 global TB prevalence and incident cases were 12 and 8.8 million respectively [2]. The vast majority of the cases (95\%) and deaths (98\%) occur in resource limited countries [3]. This situation has been

\section{() Biomed Central}


aggravating with growing problem of resistances to first line anti-TB drugs resulting in half million of new cases of multi drug resistances (MDR TB) [6,7]. Therefore, TB situation is most likely to continue to deteriorate due to multiple factors such as HIV/AIDS pandemic, poverty, low level of awareness and adverse effect of poor quality TB program [3].

Ethiopia is among the 22 High Burden Countries (HBCs) [8] and TB accounts for the major proportion of hospital admissions and reported as being the third leading cause of hospital deaths next to malaria and obstetric cases [9]. In the year 2010,the national estimate of the prevalence and incidence and mortality rates of TB were 294, 261 and 35 per 100,000 population respectively, whereas smear-positive PTB (SPPTB) cases were estimated to be 46,634 among adults aged above 15 years [2]. To reverse the impact of TB situation, TB control strategies including decentralizing/expansion of TB diagnosis and treatment services to peripheral units like health posts, private clinics, expanding health extension program (HEP) and engagement of communities through health extension workers (HEWs) have been the focus of Federal Ministry of Health [10]. One study in the southern part of Ethiopia indicated that engagement of the HEWs has improved TB case detection rate (CDR), treatment success rate (TSR), community's awareness in TB suspect identification/contact tracing activities and screening of TB patients for HIV infection [11].

Gambella Regional State (GRS) is one of the high TB burden regional sates within Ethiopia [3]. In the year 2010, 953 TB cases were detected and treated in this Regional State and among these cases 621 patients were PTB cases [12]. Even though assessment of communities' knowledge, attitude and practice (KAP) are key elements in prevention and control of TB parallel to other control strategies [3], there is no/little information on communities' KAP towards the control of TB in GRS. The objective of this study was to assess communities' KAP regarding TB in Itang Special District of the GRS, South Western Ethiopia.

\section{Methods}

\section{Study area and population}

The current study was conducted in Itang Special District of the GRS, South Western Ethiopia. Itang Special District is located at $822 \mathrm{~km}$ south west of Addis Ababa. The region shares its boards with Oromia Regional State in the North and East, Southern Nations, Nationalities and Peoples Region (SNNPRS) in the South and in the East, and the Republic of South Sudan in the West. The major ethnic groups in the region includes; Anywa, Nuer, Mezengir, Opwo and Komo. According to the 2007 housing and population census of Ethiopia [13], the region has a total population of 306,916 , consisting of 159,679 males and 147,237 females. Among the residents of the region the proportion of urban inhabitants is $25 \%$.

Recession river side agriculture is common in the region. In particular, maize and sorghum are widely practiced by Anywa and Opwo, whereas livestock constitutes the primary sources of income for Nuer community. The region has one hospital which gives routine service for urban population and provided referral service for rural people. In addition to this hospital, there are 22 health centers, 34 clinics, 108 health posts, and 16 drug venders in the region [12-14].

Itang Special District was purposely selected for the current study from the 14 districts of the region because most of its residents are indigenous and live in the remotest area of the region compared to other districts. The district has a total of 21 kebeles (small administrative units). Based on the 2007 Ethiopian National population and housing census, it has a total population of 41, 463, while rural population comprises $82 \%$.

The main indigenous ethnic groups of the District are Nuer (61\%), Anywa (30\%) and Opwo (8.5\%), and they live in stratified manner of settlements based on the ethnic group. Health service coverage is estimated to be $60.3 \%$ with 3 health centers, among which only one health center has been providing TB services for the district. In addition, there are 8 health posts in the rural areas among which only 5 have been providing health services. Malaria and TB are among the top diseases in the District $[12,14]$.

\section{Study design, sampling and data collection}

Between November 2011 and January 2012, a communitybased cross-sectional study was conducted in a randomly selected eight rural kebeles. Prior to data collection, the study kebeles were stratified in to 3 strata based on how the areas are populated by different indigenous ethnic groups (i.e. Nuer, Anywa, and Opwo). Anywa site contains 11 kebeles with a total households of 2497, Nuer site contains 8 kebeles with a total households of 5537 and Opwo site contains only one kebele with a total households of 275. Based on the number of kebeles in each strata, 4 kebeles from Anywa site (Adeng, Awanyi, Elia and Itangkir), and 3 kebeles from Nuer site (Achuwa, Mokod and Watgach) were randomly selected and the only kebele in the Opwo site (i. e. Puldeng) was included in the study. The number of households to be included in the study was determined using the formula appropriate for estimation of single proportion. As an input we assumed that, the overall level of good knowledge of the community about TB is $50 \%$ with $95 \%$ confidence in the estimate, precision of $5 \%$ and $10 \%$ of none response rate. Hence, the minimum required sample size was 422 respondents. The list of the total households of each study 
kebele was obtained from respective health extension workers (HEWs). Pre-determined sample size of 422 was proportionally allocated to each kebele based on the number of households within each kebele. Respondents from the target kebeles were selected using systematic random sampling taking the list of households as the sampling frame.

Data were collected using pre-tested structured questionnaires adopted from previous studies $[15,16]$. The questionnaires were cheeked for clarity, consistence and cultural acceptability in adjacent kebeles where the actual study didn't take place. The questionnaires were prepared in English and asked directly by translating into the local languages orally (Nuer, Anywa, and Opwo). A total of three trained diploma level nurses who are fluent in speaking and writing of indigenous language were participated in the data collection.

\section{Ethical considerations}

The study protocol was approved by the Institutional Review Board (IRB) of the Aklilu Lemma Institute of Pathobiology (ALIPB), Addis Ababa University and permission was obtained from Gambella Regional Health Bureau. The objectives of the study were explained to the study participants and verbal consent was obtained before interviewing each participant.

\section{Data analysis}

The collected data was computerized using Epi Data software Version 3.1 and exported into STATA version 11. Pearson chi-square test, univariable logistic regression analysis and multivariable logistic regression analysis were performed to explore the association between outcomes and predictor variables. Overall knowledge of the study participants about TB was assessed using six major questions and 35 sub-questions, such as source of information about $\mathrm{TB}$, able to mention cause of $\mathrm{TB}$, sign and symptoms of TB, mode of transmission of TB, risk factors for $\mathrm{TB}$, and identifying individuals at high risk for TB. For each question, a score of one was given to correct response and score of zero was given to the "do not know" response and incorrect answers. The overall knowledge score was obtained by summing these responses which is expected to range between 0 and 35 . The composite score was dichotomized using mean obtained from the data (i.e. mean $=15.2$ ). Individuals who have scored above and equal to the mean were categorized as having good level of knowledge and those who have scored below the mean knowledge score were classified as having poor level of knowledge. Similar procedures were used in defining attitude and practices as outcome variables by asking 11 and 13 questions, respectively. The questions were mainly on stigmatizing patients, wrong perceptions and what communities do before and after suffering from TB. Then, mean value of 3.2 for attitude and the mean value of 3.4 for practice were used to categorize respondents into groups having favorable versus non-favorable attitude and good practices versus poor practices, respectively.

\section{Results}

\section{Socio-demographic characteristics of the study} participants

A total of 422 study participants (58.5\% males and $41.5 \%$ females; age ranged from 19-81 years) were interviewed and the response rate was $100 \%$. The mean age of the study participants was 37 years $(\mathrm{SD}=11.6)$. About half (50.7\%) were illiterates and $70.9 \%$ were pastoralists (Table 1). With regard to ethnic composition, 127 (30.1\%) were Anywa, 281 (66.6\%) were Nuer, and 14 (3.3\%) were Opwo. Majority of the study participants (78.4\%) were followers of Protestant religion, $11.4 \%$ were Seventh day followers, $56.8 \%$ had at least 5 children and $83.7 \%$ of the respondents were married.

\section{Knowledge about the cause and signs/symptoms of TB}

Information on the knowledge of respondents about cause and symptoms of TB is summarized in Table 2. Most of the respondents (94.3\%) have heard about TB. The sources of information for the respondents were HEWs (41.9\%), TB patients (37.7\%), friends/relatives (34.4\%), school (15.6\%), public radio $(0.95 \%)$ and television (1.6\%). Alcohol consumption (42.7\%), exposure to cold air (16.6\%), germ/bacteria (3.3\%) and smoking (13.9\%) were regarded as primary causes of PTB by the respondents. The primary cause of tuberculosis lymphadenitis (TBL) was mentioned as exposure to cold air (26.1\%), smoking (17.5\%) and drinking cows' raw milk (16.6\%). Hemoptsis (60.2\%), chest pain (30.8\%), weight loss (14.7\%) and cough for two weeks and above (9.9\%) were mentioned as a major signs and symptoms of PTB.

\section{Knowledge about the mode of transmission and preventive methods of TB}

Respondents' responses regarding mode of transmission and preventive methods of $\mathrm{TB}$ are summarized in Table 3. About half (51.1\%) of the study participants said that PTB is transmit through cough and $31.3 \%$ said that both PTB and TBL can be transmitted through sharing of drinking materials. About $15 \%$ of the participants mentioned that they vaccinate their children with BCG to protect PTB and TBL. This practice was more frequent among Nuer ethnic group compared to Anywa ethnic group $(22.8 \%$ versus $0.8 \%, \mathrm{p}<0.001)$. Hygiene was mentioned as a means of preventing both PTB and TBL by $29.2 \%$ of the study participants. Forty one percent of 
Table 1 Socio-demographic characteristics of the study participants and communities' overall knowledge of TB, Itang Special District, South Western Ethiopia

\begin{tabular}{|c|c|c|c|c|c|}
\hline \multirow{2}{*}{$\begin{array}{l}\text { Characteristics } \\
\text { Sex }\end{array}$} & \multirow[t]{2}{*}{ Total number (\%) interviewed } & \multicolumn{2}{|c|}{$\begin{array}{l}\text { Level of knowledge score (max } 35 \text { ) } \\
\text { Good (Score } \geq 15.2 \text { ) poor score }\end{array}$} & \multirow[t]{2}{*}{ COR (Cl) } & \multirow[t]{2}{*}{ AOR (Cl) } \\
\hline & & & & & \\
\hline Males & $247(58.5)$ & $172(69.6 \%)$ & $75(30.4 \%)$ & 1 & 1 \\
\hline Females & $175(41.5)$ & $71(40.6 \%)$ & $104(59.4 \%)$ & $0.29(0.19,0.44)$ & $0.33(0.21,0.51)$ \\
\hline \multicolumn{6}{|l|}{ Marital status } \\
\hline Married & $353(83.7)$ & $197(55.8 \%)$ & $156(44.2 \%)$ & 1 & 1 \\
\hline Others & $69(16.3)$ & $46(66.7 \%)$ & $23(33,3 \%)$ & $1.58(0.92,2.73)$ & $2.08(1.02,4.27)$ \\
\hline \multicolumn{6}{|l|}{ Age categories } \\
\hline $19-29$ & $122(28.9)$ & $66(54.0 \%)$ & $56(46.0 \%)$ & 1 & 1 \\
\hline $30-44$ & $198(46.9)$ & $131(66.2 \%)$ & $67(33.8 \%)$ & $1.65(1.04,2.63)$ & $3.13(1.75,5.61)$ \\
\hline $45-59$ & $77(18.3)$ & $39(50.6 \%)$ & $38(49.4 \%)$ & $0.87(0.49,1.54)$ & $1.93(0.91,4.09)$ \\
\hline$\geq 60$ & $25(5.9)$ & 7 (28.0\%) & $18(72.0 \%)$ & $0.32(0.12,0.84)$ & $0.78(0.26,2.32)$ \\
\hline \multicolumn{6}{|l|}{ Sites } \\
\hline Anywa & $127(30.1)$ & $106(83.5 \%)$ & $21(16.5 \%)$ & 1 & 1 \\
\hline Nuer & $281(66.6)$ & $125(44.5 \%)$ & $156(55.5 \%)$ & $0.15(0.09,0.26)$ & $0.205(0.11,0.36)$ \\
\hline OPwo & $14(3.3)$ & $12(85.7 \%)$ & $2(14.3 \%)$ & $1.18(0.24,5.70)$ & $1.63(0.32,8.18)$ \\
\hline \multicolumn{6}{|l|}{ Education } \\
\hline Illiterate & $214(50.7)$ & $116(54.2 \%)$ & $98(45.8 \%)$ & 1 & 1 \\
\hline Read \& write & $59(14.0)$ & $33(55.9 \%)$ & $26(44.1 \%)$ & $1.07(0.60,1.91)$ & $0.85(0.43,1.67)$ \\
\hline Primary school & $96(22.8)$ & $52(54.2 \%)$ & $44(45.8 \%)$ & $0.99(0.61,1.61)$ & $0.854(0.43,1.67)$ \\
\hline Secondary school and above & $53(12.6)$ & $42(79.3 \%)$ & $11(20.8 \%)$ & $3.22(1.57,6.60)$ & $3.076(1.08,8.68)$ \\
\hline \multicolumn{6}{|l|}{ Occupation } \\
\hline Pastoralist & 199 (70.9) & $160(53.2 \%)$ & $139(46.5 \%)$ & 1 & 1 \\
\hline Merchant & $13(3.1)$ & $7(53.5 \%)$ & $6(46.6 \%)$ & $1.01(0.33,3.08)$ & $0.65(0.19,2.13)$ \\
\hline Students & $39(9.2)$ & $29(74.4 \%)$ & $10(25.6 \%)$ & $2.519(1.18,5.35)$ & $1.41(0.57,3.49)$ \\
\hline Employees & $71(16.8)$ & $47(66.2 \%)$ & $24(33.8 \%)$ & $1.70(0.98,2.92)$ & $1.38(0.61,3.08)$ \\
\hline
\end{tabular}

COR crude odd ratio, $A O R$ adjusted odd ratio.

the study participants mentioned "avoiding of smoking" as the most important method of preventing and control of PTB. About $90 \%$ of the study participants said that PTB is treatable with modern drugs, whereas $37.4 \%$ said that they treat TBL by burning the swelling sites with heated metal materials culturally.

Twenty two percent of the study participants reported that at least one of their families' members had previous history of PTB and treated with modern drugs at health centers. About half of the study participants prefer to consult CHEWs in case they and their families sick from PTB. However, participants from Nuer site were less likely to consult CHEWs compared to participants from Opwo site $(40.9 \%$ versus $78.6 \%, \mathrm{P}<0.001)$. Forty five percent of the participants preferred health center for the treatment of major sign/symptoms of PTB, whereas $42.7 \%$ of the participants preferred to be treated for major sign/symptoms of PTB in health posts.

\section{Communities' overall knowledge about TB}

The level of overall knowledge generated using the composite knowledge score is summarized in Table 1. Of the total study participants $243(57.6 \% 95 \% \mathrm{CI}, 52.7 \%$ to 62.3\%) had good level of knowledge about TB. Female participants (adjusted odd ratio, $\mathrm{AOR}=0.33,95 \% \mathrm{CI}$, 0.21 to $0.51, \mathrm{p}<0.002$ ) and participants from Nuer site (AOR $=0.21$; 95\% CI: 0.11 to 0.36 ) had low level of overall knowledge about TB. Being in the age categories of 30-44 years compared to 19-29 years of age group $(\mathrm{AOR}=3.14,95 \% \mathrm{CI}, 1.76$ to $5.62, \mathrm{p}<0.001)$ and being relatively well educated than being illiterate $(\mathrm{AOR}=3.08$, $95 \% \mathrm{CI}, 1.09$ to $8.68, \mathrm{p}=0.001$ ) had good level of overall knowledge about TB.

\section{Communities' attitude/perception towards TB}

Summary information about the attitude of study participants about TB is summarized in Table 4. From the 
Table 2 Communities' knowledge about the cause, sign and symptoms of TB, Itang Special District, GRS, South Western Ethiopia

\begin{tabular}{|c|c|c|c|c|c|}
\hline Variable & Response categories & Anywa site & Nuer site & Opwo site & Total \% \\
\hline \multirow[t]{8}{*}{ Cause of PTB } & & Number (\%) & Number (\%) & Number (\%) & Number (\%) \\
\hline & Bacteria & $8(6.3)$ & $6(2.1)$ & $0(0.0)$ & $14(3.3)$ \\
\hline & Cold air & $8(6.3)$ & $51(18.2)$ & $11(78.6)$ & $70(16.6)$ \\
\hline & Hot climate & $1(0.8)$ & $5(1.8)$ & $0(0.0)$ & $6(1.4)$ \\
\hline & Shortage of food & $17(13.4)$ & $4(1.4)$ & $1(7.1)$ & $22(5.2)$ \\
\hline & Alcohol & $81(63.8)$ & $86(30.6)$ & $13(92.8)$ & $180(42.7)$ \\
\hline & Smoking & $14(11.1)$ & $40(14.2)$ & $5(35.7)$ & $59(13.9)$ \\
\hline & Don't know & $4(3.2)$ & $143(50.8)$ & $4(3.2)$ & 151 (33.6) \\
\hline \multirow[t]{4}{*}{ Cause of (TBL) } & Bacteria & $4(3.2)$ & $5(1.8)$ & $0(0.0)$ & $9(2.1)$ \\
\hline & Cold air & $45(35.4)$ & $58(20.6)$ & $7(50.0)$ & $110(26.1)$ \\
\hline & Smoking & $42(33.1)$ & $30(10.7)$ & $2(14.3)$ & $74(17.5)$ \\
\hline & Drinking cow raw milk & $40(31.5)$ & $27(9.6)$ & $3(21.4)$ & $70(16.6)$ \\
\hline \multirow[t]{5}{*}{ Signs and symptoms of PTB } & Cough for 2 weeks \& above & $29(22.8)$ & $10(3.6)$ & $3(21.4)$ & $42(9.9)$ \\
\hline & Weight loss & 35 (27.6) & $20(7.1)$ & $7(50.0)$ & $62(14.7)$ \\
\hline & Hemoptsis & 81 (63.8) & $176(59.4)$ & $6(42.8)$ & $254(60.2)$ \\
\hline & Chest pain & $60(47.2)$ & $69(24.5)$ & $1(7.1)$ & $130(30.8)$ \\
\hline & Don't know & $3(2.4)$ & 88 (31.3) & $0(0.0)$ & 91 (19.2) \\
\hline
\end{tabular}

total of 422 study participants, $263(58 \%)$ mentioned PTB as killer disease even after treatment, whereas 138 (34.1\%) said that it affects only poor people. Thirty (7.1\%) respondents reported that they don't share food and drink with TB patient, while 257 (59\%) said that TB patients should feel shame which was highly reflected among participants from Nuer site (85.8\%). About 40.8\% (95\%CI, $36.0 \%$ to $45.6 \%$ ) of the study participants had favorable attitude towards TB. Low favorable attitude was significantly associated with female gender $(\mathrm{AOR}=0.23$, 95\% CI, 0.14 to 0.37 ). Favorable attitude towards TB patients was significantly associated with high educational

Table 3 Communities' knowledge about mode of transmission and preventive methods of TB, Itang Special District, GRS, South Western Ethiopia

\begin{tabular}{|c|c|c|c|c|}
\hline Variables & Anywa site & Nuer site & Opwo site & Total \\
\hline Is PTB transmittable? & Number (\%) & Number (\%) & Number (\%) & Number (\%) \\
\hline Yes & $114(89.8)$ & $219(77.9)$ & $13(92.8)$ & $346(81.9)$ \\
\hline No & $13(10.2)$ & $62(22.1)$ & $1(7.1)$ & $76(16.2)$ \\
\hline \multicolumn{5}{|l|}{ Mode of TB transmission } \\
\hline Transmits through cough (PTB) & $65(51.1)$ & $142(50.5)$ & $10(71.4)$ & $272(51.4)$ \\
\hline Through sharing drinking (TBL and PTB) & $46(36.2)$ & $76(27.1)$ & $10(71.4)$ & $132(31.3)$ \\
\hline Through sharing food (TBL and PTB) & $18(14.2)$ & $69(24.5)$ & $10(71.4)$ & $97(22.9)$ \\
\hline \multicolumn{5}{|l|}{ Prevention and control of TB } \\
\hline BCG vaccination (PTB and TBL) & $1(0.8)$ & $64(22.8)$ & $0(0.0)$ & $65(15.4)$ \\
\hline Hygiene (PTB and TBL) & $28(22.1)$ & $90(32.1)$ & $5(35.7)$ & $123(29.2)$ \\
\hline Avoid smoking (PTB) & $87(68.5)$ & $76(27.1)$ & $10(71.4)$ & $173(41.0)$ \\
\hline Isolate patient with PTB & $16(12.5)$ & $8(2.9)$ & $5(35.7)$ & $29(6.8)$ \\
\hline Cover mouth when cough for PTB & $21(16.5)$ & $2(0.7)$ & $7(50.0)$ & $30(7.1)$ \\
\hline Avoid drinking raw milk for $\mathrm{TBL}$ & $51(40.2)$ & $21(7.5)$ & $8(57.1)$ & $80(18.9)$ \\
\hline Consult health extension workers incase sick from PTB & $95(74.8)$ & $115(40.9)$ & $11(78.6)$ & $221(52.4)$ \\
\hline Prefer traditional healers for treatment (TBL) & $33(25.9)$ & $157(55.8)$ & $1(7.2)$ & $191(45.3)$ \\
\hline Prefer health post for treatment (PTB) & $33(25.9)$ & $143(50.9)$ & $4(28.5)$ & $180(42.7)$ \\
\hline
\end{tabular}


Table 4 Communities' attitude towards TB, rural of Itang Special District, GRS, South Western Ethiopia, 2012

\begin{tabular}{|c|c|c|c|c|}
\hline \multirow{2}{*}{$\begin{array}{l}\text { Characteristics } \\
\text { Sex }\end{array}$} & \multicolumn{2}{|l|}{ Level of attitude } & \multirow[t]{2}{*}{ Crude OR (Cl) } & \multirow[t]{2}{*}{ AOR (Cl) } \\
\hline & Favorable $\geq 3.2$ & Unfavorable $<3.2$ & & \\
\hline Males & $128(51.8 \%)$ & $119(48.2 \%)$ & 1 & 1 \\
\hline Females & $44(25.1 \%)$ & $131(74.9 \%)$ & $0.31(0.20,0.48)$ & $0.22(0.13,0.37)$ \\
\hline \multicolumn{5}{|l|}{ Age categories } \\
\hline$(19-29)$ & $63(51.6 \%)$ & $59(48.4 \%)$ & 1 & 1 \\
\hline$(30-44)$ & $74(37.4 \%)$ & $124(62.4 \%)$ & $0.55(0.35,0.88)$ & $1.35(0.77,2.37)$ \\
\hline$(45-59)$ & $29(37.6 \%)$ & $48(62.4 \%)$ & $0.87(0.49,1.54)$ & $1.93(0.91,4.09)$ \\
\hline$\geq 60$ & $6(24.0 \%)$ & 19 (76.0\%) & $0.32(0.12,0.87)$ & $0.78(0.26,2.32)$ \\
\hline \multicolumn{5}{|l|}{ Sites } \\
\hline Anywa & $45(35.4 \%)$ & $82(64.5 \%)$ & 1 & 1 \\
\hline Nuer & 115 (40.9\%) & $166(59.1 \%)$ & $1.26(0.82,1.95)$ & $1.49(0.82,2.23)$ \\
\hline OPwo & $12(85.7 \%)$ & $2(14.3 \%)$ & $10.93(2.34,51.02)$ & $13.30(2.77,63.96)$ \\
\hline \multicolumn{5}{|l|}{ Educational status } \\
\hline Illiterate & $62(28.9 \%)$ & $152(71 \%)$ & 1 & 1 \\
\hline Read \& write & $24(40.7 \%)$ & $35(59.3 \%)$ & $1.68(0.92,3.05)$ & $1.26(0.64,2.49)$ \\
\hline Primary school & 49 (51\%) & 47 (48.9\%) & $2.55(1.55,4.20)$ & $2.26(1.15,4.45)$ \\
\hline Secondary school \& above & $37(69.8 \%)$ & $16(30.2 \%)$ & $5.66(2.94,10.93)$ & $4.77(1.77,12.83)$ \\
\hline \multicolumn{5}{|l|}{ Occupational status } \\
\hline Pastoralist & $96(32.1 \%)$ & $203(67.9 \%)$ & 1 & 1 \\
\hline Merchant & $8(61.5 \%)$ & $5(38.5 \%)$ & $3.38(1.07,10.61)$ & $3.88(1.00,15.02)$ \\
\hline Students & $25(64 \%)$ & 14 (35.9\%) & $3.77(1.87,7.58)$ & $3.522(1.51,8.17)$ \\
\hline Employees & $43(60.6 \%)$ & 28 (39.4\%) & $3.24(1.90,5.54)$ & $3.554(1.94,6.49)$ \\
\hline \multicolumn{5}{|l|}{ Knowledge } \\
\hline Poor & 179 (56.6\%) & 141 (43.4\%) & 1 & 1 \\
\hline Good & $243(57.6 \%)$ & 109 (42.4\%) & $4.78(2.81,8.15)$ & $5.92(3.53,9.92)$ \\
\hline
\end{tabular}

level of the study participants $(\mathrm{AOR}=4.78,95 \% \mathrm{CI}, 1.78$ to 12.83). Occupation of the participants other than pastoralist were also associated with favorable attitude towards $\mathrm{TB}(\mathrm{AOR}=5.92,95 \% \mathrm{CI}, 3.53$ to 9.92$)$.

\section{Communities' overall practices regarding prevention and control of TB}

Information about the overall practice of the communities is summarized in Table 5. Less than half of the participants $(45.9 \% 95 \% \mathrm{CI}, 41.1 \%$ to $50.9 \%)$ had good practices. Poor practices of prevention and control of TB was significantly associated with female participants $(\mathrm{AOR}=0.37,95 \% \mathrm{CI}, 0.24$ to $0.57, \mathrm{p}<0.001)$.

\section{Discussion}

The results of this community-based cross-sectional study showed that most of the community's members of Itang Special District have information about TB. The finding is similar to the results of studies from Afar Region [16], South West Ethiopia [17] and North Ethiopia [15,18], Malaysia [19] and rural China [20]. The main sources of information mentioned by the study participants are also similar to the findings of study conducted in other part of Ethiopia [15]. In the current study, very few participants mentioned mass media as a source of information about TB which is inconsistent with studies done in Lahore [21], Iraq [22] and Pakistan [23] in which most of the study participants' mentioned mass media as a major source of information about TB.

Despite a higher proportion of the study participants have heard about TB, the majority had no/little knowledge about the cause of the disease. Only 3.3\% of the participants correctly answered the cause of TB as being germ/bacteria which is in agreement with the findings of study from other part of Ethiopia [16]. Cold air, alcohol consumption, smoking and shortage of food were frequently mentioned as the cause of PTB by the present study participants which is similar to the findings of studies in Tigray, Afar and North Ethiopia [15,16,18], but differ from the findings of previous study on TB suspects in a rural community of southwest Ethiopia, in which sizeable number of the study participants 
Table 5 Communities' practices towards TB prevention and control, Itang Special District, GRS

\begin{tabular}{|c|c|c|c|c|}
\hline \multirow[t]{2}{*}{ Characteristics } & \multicolumn{2}{|c|}{ Level of practices } & \multirow[t]{2}{*}{ Crude OR (Cl) } & \multirow[t]{2}{*}{ AOR (Cl) } \\
\hline & Good $\geq 3.4$ & Poor $<3.4$ & & \\
\hline \multicolumn{5}{|l|}{ Sex } \\
\hline Males & $138(55.8 \%)$ & $109(44.2 \%)$ & 1 & 1 \\
\hline Females & $56(32 \%)$ & $119(68 \%)$ & $0.37(0.24,0.55)$ & $0.36(.24,0.56)$ \\
\hline \multicolumn{5}{|l|}{ Marital status } \\
\hline Married & $154(43.6 \%)$ & 199 (56.4\%) & 1 & 1 \\
\hline Others & 40 (57.9\%) & $29(42.0 \%)$ & $1.78(1.05,3.00)$ & $1.61(0.93,2.80)$ \\
\hline \multicolumn{5}{|l|}{ Age categories } \\
\hline$(19-29)$ & 60 (49. 2\%) & $62(50.2 \%)$ & 1 & 1 \\
\hline (30-44) & $92(46.5 \%)$ & $106(53.2 \%)$ & $0.89(0.57,1.40)$ & $1.33(0.78,2.25)$ \\
\hline$(45-59)$ & $34(44.5 \%)$ & $43(55.8 \%)$ & $0.81(0.46,1.44)$ & $1.54(0.77,3.11)$ \\
\hline$\geq 60$ & $8(32.0 \%)$ & $17(68.0 \%)$ & $0.48(0.19,1.21)$ & $1.04(0.37,2.88)$ \\
\hline \multicolumn{5}{|l|}{ Sites } \\
\hline Anywa & $74(58.3 \%)$ & $53(41.7 \%)$ & 1 & 1 \\
\hline Nuer & $107(38.1 \%)$ & $174(61.9 \%)$ & $0.44(0.28,0.67)$ & $0.58(0.35,0.96)$ \\
\hline OPwo & 13 (92.9\%) & $1(7.1 \%)$ & $9.31(1.18,73.36)$ & $14.5(1.78,11.85)$ \\
\hline \multicolumn{5}{|l|}{ Educational status } \\
\hline Illiterate & 89 (41.5\%) & $125(58.4 \%)$ & 1 & 1 \\
\hline Read \& write & $29(49.2 \%)$ & $30(50.5 \%)$ & $1.35(0.76,2.42)$ & $1.17(0.62,2.23)$ \\
\hline Primary school & $45(46.9 \%)$ & $51(53.1 \%)$ & $1.23(0.76,2.01)$ & $0.93(0.48,1.76)$ \\
\hline Secondary school \& above & 31 (58.9\%) & $22(41,5 \%)$ & $1.97(1.07,3.64)$ & $1.15(0.46,2.82)$ \\
\hline \multicolumn{5}{|l|}{ Occupational status } \\
\hline Pastoralist & $122(40.8 \%)$ & $177(59.2 \%)$ & 1 & 1 \\
\hline Merchant & 7 (53.9\%) & $6(46.2 \%)$ & $1.69(0.55,5.15)$ & $1.58(0.47,5.26)$ \\
\hline Students & $24(61.5 \%)$ & $15(38.5 \%)$ & $2.32(1.17,4.61)$ & $2.31(1.01,5.30)$ \\
\hline Employees & $41(57.8 \%)$ & $30(42.3 \%)$ & $1.98(1.17,3.34)$ & $2.25(1.05,4.82)$ \\
\hline \multicolumn{5}{|l|}{ Knowledge } \\
\hline Poor & 179 ((59.6\%) & $147(40.4 \%)$ & 1 & 1 \\
\hline Good & $243(64.6 \%)$ & $81(35.4 \%)$ & $8.52(5.07,14.32)$ & $9.64(5.76-16.01)$ \\
\hline
\end{tabular}

mentioned bacteria as the cause of TB [17]. The difference might be due to early deployment of HEWs in the previous study area as compared to the present study area [9]. In addition to this, a rural community of South West Ethiopia has been exposed to students' practicum program from Medical school of the Jimma University. Hence, relatively information on $\mathrm{TB}$ might be easily disseminated among that community as compared to the present studied community [24].

In previous studies conducted in varies parts of Ethiopia [15-18], the majority of the study participants identified persistent productive cough as the major signs and symptoms of PTB. In the present study, persistent productive cough was mentioned as signs and symptoms of PTB by very few study participants. The discrepancies might be due to socio-cultural factors such as smoking of Gaya by most of the indigenous in the present study area [12].

Gaya is a local name given to instrument used to prepare and suck after tobacco, few drops of water is added and roasted with fire gently until evaporation starts to make it comfortable for sucking. It causes addiction like any other addiction causative substances such as cigarette. It causes productive cough among smokers. This situation misleads perception of the communities in that, productive cough is caused by smoking of Gaya rather than due to PTB and delay them from early diagnosis and treatment of PTB. Results of the present study regarding the signs and symptoms of PTB are also inconsistent with the findings of other studies conducted elsewhere [20,21] in which majority of the participants mentioned 
persistent productive cough as major signs and symptoms of PTB.

In this study, the study participants reported that PTB is treatable and curable with modern drug which is consistence with the findings of previous studies in other parts of Ethiopia [15,16], in Iraq [22], in South Africa [25] and in Tajikistan [26]. However, the finding of the current study is different from the results of previous studies conducted in south part of Ethiopia [27] and in Tanzania in which greater than half of the study participants reported roots bark from trees, oil from meat, blood, and fat as the effective treatment for TB [28]. High level of awareness of the communities about the appropriate treatment of the disease could have significant implications in reducing diagnosis and treatment delay, as well as the spread of the disease.

The present study showed that a considerable proportion of the study participants had unfavorable attitude towards TB patients which could potentially create ground for stigmatization of TB patients in the communities $[18,25,29]$. On the other hand, the participants recognized that specific groups of population/individuals such as poor, people living with HIV/AIDS, alcohol consumption and smokers are at high risk of getting TB which corroborates the findings of previous studies conducted in Ethiopia [15-17], in India [29], Vietnam [30] and Tajikistan [26]. More than half of the study participants thought that TB is killer even after treatment in patients who have low socio economic status, which is similar to the finding of study conducted in West Bengal in which the majority of the study participants including community leaders felt that poor people cannot be cured completely from TB by treatment [31].

The study participants indicated that the communities in the present study area are engaged in different practices such as cultural and modern facility based mixed approaches of treatments for TBL. A considerable proportion $(45 \%)$ of the study participants said that they consult traditional healers for the treatment of TBL, and the traditional healers treat the site of swelling by burning with metal materials. Study in other part of Ethiopia indicated that patients with TBL are treated with herbal medicine by traditional healers [16]. The discrepancies in traditional ways of treatment of TBL might be aroused from several factors like cultural and environmental differences of the studied communities.

About half of the study participants' consult HEWs for the treatment of PTB at health post levels which disagrees with findings of previous study in North part of Ethiopia [18] in which majority of the PTB suspects visited medical health providers at health centers and hospitals levels, where there are trained man power, diagnostic facilities and anti TB regimens relatively available. This difference might be due to early deployment of community's HEWs in the previous study area [9]. In addition to this, majority of the present study communities are highly mobile as compared to the previous study which make difficult to provide health education on the medical importance of TB [14].

In this study, it was noted that, majority of the participants from the Nuer site had low level of overall knowledge; attitude and practices of $\mathrm{TB}$ compared to participants from Opwo and Anywa sites. This difference might be linked to mobility of the community as most of the inhabitants of Nuer are pastoralists which make it difficult to provide health education on the importance of medical care for TB by HEWs. The results of the study conducted in Malaysia showed absence of significant association between score on general knowledge and attitude towards TB with age, gender and educational levels of the study participants [19]. In the present study, it was found that female participants had low level of favorable attitude and poor practices towards the prevention of $\mathrm{TB}$ as compared to male participants. The finding is in agreement with previous study done in Ethiopia [15] and studies done elsewhere [29,32-34]. Hence, community based health education which focuses on pastoral community and females' inhabitants could be important to improve their knowledge, attitude and practices of TB in the present study area.

\section{Conclusion}

The results of this study revealed a low level of knowledge about the causative agent as well as about the main symptom of TB in the present study communities. In addition, the study showed low level of overall knowledge, unfavorable attitude and poor practices towards TB especially in participants from Nuer site and females. Hence, public health education on the cause, symptoms and mode of transmission of TB would be important towards the prevention and control of TB in the present study area.

\section{Competing interests}

The authors have no competing interests.

\section{Authors' contributions}

JB designed the study, collected data, analysis and drafted the manuscript. ML participated in study design and write up. GM participated in study design, data analysis and write-up. All authors read, critically revised and approved the final manuscript. ML is the guarantor of the paper.

\section{Acknowledgements}

We would like to extend our thanks to Addis Ababa University, Aklilu Lemma Institute of Pathobiology for financial support. We would also like to acknowledge the study participants, the community leaders and data collectors.

\section{Author details}

'Gambella Teachers Education and Health Science College, Gambella, Ethiopia. ${ }^{2}$ Addis Ababa University, Aklilu Lemma Institute of Pathobiology, Addis Ababa, P.O. Box, 1176, Ethiopia.

Received: 21 October 2012 Accepted: 30 July 2013

Published: 7 August 2013 


\section{References}

1. World Health Organization: Global tuberculosis control. India: Regional Office for South East Asia New Delhi; 2002.

2. World Health Organization: Global tuberculosis control. Geneva, Switzerland; 2011.

3. World Health Organization: Global Tuberculosis Control. Addis Ababa, Ethiopia: Country Profile; 2009.

4. Auer C, Sarol JJ, Tanner M, Weiss M: Health seeking and perceived causes of tuberculosis among patients in Manila. J Trop Med Int Health 2000, 5:648-56.

5. Yimer S, Bjune G, Alene G: Diagnostic and Treatment delay among pulmonary tuberculosis patients in Ethiopia: a cross sectional study. BMC Infect Dis 2005, 5:112.

6. Blasco P, Bonte L, Frigati L, Humbulet P, Martin A, Sizaire V: Medicine Sans Fronti ers (MSF): tuberculosis: practical guide line $5^{\text {th }}$ revised edn on tuberculosis for clinicians, nurses, laboratory technicians and medical auxiliaries, Paris. France 2010, 25:27.

7. Lawn SD, Wood R, Wilkinson RJ: Changing concepts of latent tuberculosis infection in patients living with human immune deficiency virus infection. Clin Dev Immunol 2011, 2011:1-2.

8. World Health Organization: Global Tuberculosis control: surveillance. Geneva, Switzerland: planning, financing; 2008.

9. Federal Ministry of Health: Ethiopia: $\mathrm{FMOH} 2008 / 9$ report: Health and health related indicators Planning and Programming Department Addis Ababa; 2008.

10. Federal Ministry of Health: Tuberculosis Prevention and Control Program. Addis Ababa, Ethiopia: Special issue for World tuberculosis Day 24th March 2011; 2011.

11. Datiko DG, Lindtjørn B: Health extension workers improve tuberculosis case detection and treatment success in Southern Ethiopia: a community randomized trial. PLOS ONE 2009, 4:e5443.

12. Gambella Regional Health Bureau: Planning and program Department. GRHB 2011 report; 2011.

13. Central stastical authority: Central stastical authority. Ethiopia: Addis Ababa; 2008.

14. Endeshaw T, Gebre T, Ngondi J, Graves PM, Shargie EB, Ejigsemahu Y, Ayele B, Yohannes G, Teferi T, Messele A, Zerihun M: Evaluation of light microscopy and rapid diagnostic test for the detection of malaria under operational field conditions a household survey in Ethiopia. MBC Malaria J 2007, 7:118.

15. Mesfin MM, Tasew TW, Tareke IG, Mulugeta GWM, Richard MJ: Community knowledge, attitudes and practices on pulmonary tuberculosis and their choice of treatment supervisor in Tigray, northern Ethiopia. Ethiop J Health Dev 2005, 19:25

16. Legesse M, Ameni G, Mamo G, Medhin G, Shawel D, Bjune G, Abebe F: Knowledge and perception of pulmonary tuberculosis in pastoral communities in the middle and lower Awash Valley of Afar region, Ethiopia. BMC Public Health 2010, 10:187.

17. Abebe G, Deribew A, Apers L, Woldemichael K, Shifa J, Tesfaye M, Abdisa A, Deribie F, Jira C, Bezabih M, Assefa A, Duchateau L, Colebunders R: Awareness, healthcare seeking behavior and perceived stigma towards tuberculosis among tuberculosis suspects in a rural community in Southwest Ethiopia. PLoS One 2010, 5:10.

18. Yimer $\mathrm{S}$, Hansen $\mathrm{CH}$, Yimaldu T, Bjune $\mathrm{G}$ : Health care seeking among pulmonary tuberculosis suspects and patients in rural Ethiopia: a community-based study. BMC Public Health 2009, 9:454.

19. Koay TK: Knowledge and attitudes towards tuberculosis among the people living in Kudat District, Sabah. Med J Malaysia 2004, 59:1-2.

20. Wang J, Fei1 Y, Shen H, Biaoxu B: Gender difference in knowledge of tuberculosis and associated health-care seeking behaviors: rural area of China. BMC Public Health 2008, 8:354

21. Christina MN, Domingo B, Ong-lim AL: A Descriptive study of the knowledge, attitudes and practices on tuberculosis among treatment partners of pediatric patients in Tarlac. PIDSP 2009, 10:2-4.

22. Hashim DS, Kubaisy WA, Dulayme AA: Knowledge, attitudes and practices survey among health care workers and tuberculosis patients in Iraq. Eas Medit Health I 2003, 9:721-722.

23. Umair M, Ubeera M, Hussain $S$, Abdullah M, Saeed A, Omer F, Shad MA, Siddiqui AM, Akram J: Urban-rural inequities in knowledge, attitudes and practices regarding tuberculosis in two districts of Pakistan's Punjab province BMC Int J Equ. Health 2011, 10:8.

24. Tegegne M, Asefa M, Tessema F, Kebede K: Assessment of the community- based training programme at Jimma University, Ethiopia. Ethiop J Health Dev 2000, 14:239-252.
25. Cramm JM, Finkenflügel HJM, Møller VP, Nieboer A: Tuberculosis treatment initiation and adherence in a South African community influenced more by perceptions than by knowledge of tuberculosis. BMC Public Health 2010, 10:72.

26. Gilpin C, Colombani P, Hasanova S, Sirodjiddinova U: Exploring tuberculosis related knowledge, attitude, behavior, and practice among migrant workers in Tajikistan. Tuberc Res Treat 2011, 10:21-25.

27. Vecchiato NL: Socio-cultural aspects of tuberculosis control in Ethiopia. Med Anthropol Quarter 1997, 11:183-201.

28. Egwaga S, Range N, Lwilla F, Mkopi A, Barongo V, Mtenga S, Mashinda H, Cobelens F, Haag V, Leth FV, Grewal P: Assessment of patient preference in allocation and observation of anti-tuberculosis medication in three districts in Tanzania. Dove Medical Press 2008, 2:2-3.

29. Yadav SP, mathur M, Dixit AK: Knowledge and attitude towards tuberculosis among sandstone quarry workers in desert parts of Rajasthan. Indian J Tuberc 2006, 53:187-195.

30. Johansson E, Diwan VK, Huong ND, Ahlberg BM: Staff and patient attitude to tuberculosis and compliance with treatment in Vietnam. Tuber Lung Dis 1996, 2:178-83.

31. Gehtakrishnan K, Pappu KP, Roychowdkury MRS: Study on knowledge and towar ds tuberculosis in a rural area of West Bengal. Ind J Tubec 1988, 35:83-84.

32. Wu PS, Pesus Chou P, Chang NT, Sun WJ, Hsu S, Kuo HS: Assessment of changes in knowledge and stigmatization following tuberculosis training workshops in Taiwan. J Formos Med Assoc 2009, 108:380-382.

33. Ali M, Hadi E, Jalilvand M, Hadian M: Assessment of the amount of knowledge and attitude of Tehran high school students regarding tuberculosis. Tanaffos 2006, 5:23-28.

34. Haasnoot PJ, Boeting TE, Kuney MO, Roosmalen JV: Knowledge attitude and practice of tuberculosis among Maasai in Simanjiro District, Tanzania. Am Soc Trop Med Hygi 2010, 83:902-903.

doi:10.1186/1471-2458-13-734

Cite this article as: Bati et al: Community's knowledge, attitudes and practices about tuberculosis in Itang Special District, Gambella Region, South Western Ethiopia. BMC Public Health 2013 13:734

\section{Submit your next manuscript to BioMed Central and take full advantage of:}

- Convenient online submission

- Thorough peer review

- No space constraints or color figure charges

- Immediate publication on acceptance

- Inclusion in PubMed, CAS, Scopus and Google Scholar

- Research which is freely available for redistribution 